\title{
Preliminary Study of Sieves Analysis of Fiber Oil Palm Trunk Which Potential as Building Material
}

\author{
Kinanti Wijaya ${ }^{1}$, Ameilia Zuliyanti Siregar ${ }^{2}$, Sutrisno ${ }^{1}$ \\ ${ }^{1}$ Faculty of Engeenering, University Negeri Medan \\ ${ }^{2}$ Faculty of Agriculture, University Sumatera Utara
}

\section{Introduction}

The increasing growth of oil palm plantations will cause problems of waste generated both from factories or oil palm plantations. Palm trees have reached the age of 25 years and over must begin to do pemudaan back (replanting). Utilization of oil palm trunk result of replanting is still not optimal do. Oil palm trunk of the plant types monocots then the stem is not kambium and generally unbranched. Based on research Bakar et al. (1998), oil palm wood is only taken on the edge of a relatively hard so that the resulting yield of $30 \%$ or $0.30 \mathrm{~m}^{3}$ of each $\mathrm{m}^{3}$. In 1998, there were more than 180,000 ha of palm trees aged above 25 years. Based on these data Bakar et al. (1998) estimates that can be produced more than 16 million $\mathrm{m} 3$ of oil in the form of logs, which can produce about 5 million $\mathrm{m} 3$ of sawn wood, not including the central part of the stem is soft. This demonstrates the potential to address the needs of the construction timber industry.

Based on research Iswanto et al (2010) that the longitudinal direction of the stem has the physical and mechanical properties are better at the base of the stem. And directions rod horizontally, the edge of the stem has physical and mechanical properties are better than the middle and deep. Palm trunks fit the edges used as lightweight construction materials and furniture because it has physical and mechanical properties are better, while the middle and the center (inside) can be used as raw material particle board or other biocomposite products.

Oil palm trunk were found to be highly abundant and considered as agricultural waste may be used as an alternative for wood in the future. ASTE palm trunks for non-structural purposes. These rods are not seen from the economic necessity but judging from its natural form. The growth of oil palm trees are more conserved world especially in Indonesia because of the fruit until the waste can be utilized both in terms of agriculture, energy, and engineering. The resulting waste in the form of oil palm trunk, leaves oil palm empty fruit bunches and palm fiber, palm shells and palm oil mill effluent.

Provision of initial treatment in the form of palm coconut coir fiber soaking treatment is known to dissolve the extractive substances that are expected to add to the quality of the resulting board.

Table 1. U.S. Standard sieve number

\begin{tabular}{|l|l|}
\hline U.S. Standard Sieve No. & Sieve Opening (mm) \\
\hline 1,5 -in & 37.5 \\
\hline 0,75 -in & 19.0 \\
\hline 0,375 -in & 9.5 \\
\hline 4 & 4.75 \\
\hline 8 & 2.35 \\
\hline 30 & 0,600 \\
\hline 40 & 0,425 \\
\hline 50 & 0,300 \\
\hline 100 & 0,150 \\
\hline 200 & 0,075 \\
\hline
\end{tabular}

The research of analysis sieve of fiber of oil palm trunk samples are limited done. Because kebutuhan penggunaan This aims of study to determine the distribution of the sample size by using a suitable sieve.

\section{Metodology}

The research was conducted in the laboratory of the State University of Medan. The method used is the method of experiment. Oil palm trunk who have reached the age of replanting in pieces at the bottom of the trunks of palm trees. Furthermore, the rod is cleaned and dried until the moisture content reaches less than 10\%.

The process of collecting oil palm trunk fiber by using planers machines. The size of oil palm trunk used is $5 \times 20 \mathrm{~cm}, 20 \times 20 \mathrm{~cm}$, between $25 \times 25 \mathrm{~cm}$, and. Then three different sizes of the oil palm trunks planed using planers machine type CKM P.20. Fibers produced from this harvest into three variations. Further testing sieve. Each specimen is filtered through a sequential arrangement using U.S. Standard sieve. Machine filter was rocked for 15 minutes. Furthermore, the test specimen is weighed based on a sample left on each layer. 
a) Sample 1

\section{Analysis of Data}

The size of oil palm trunk for sample 1 is $5 \times 20 \mathrm{~cm}$. Results are reaping the stem size there are a lot of fiber size of $0.075 \mathrm{~mm}$ while the size of the fiber that is at least $2.36 \mathrm{~mm}$. If seen from the graph 1 to the filter sample 1 can be said that the distribution of the fiber sample 1 is not homogeneous but fine fibers predominate.

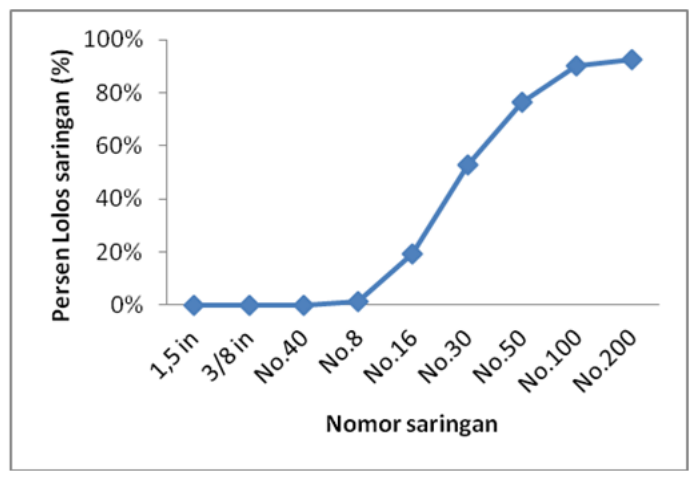

b) Sample 2

The size of oil palm trunk to sample 2 is $20 \times 20 \mathrm{~cm}$. Results are reaping the stem size there are a lot of fiber size of $0.075 \mathrm{~mm}$ while the size of the fiber that is at least $9.50 \mathrm{~mm}$. If seen from the graph 2 for the filter sample 2 can be said that the fiber distribution is not homogeneous sample 2 and the size varies with the fiber already has a coarse fiber size with a large amount is $1.18 \mathrm{~mm}$ and $2,36 \mathrm{~mm}$.

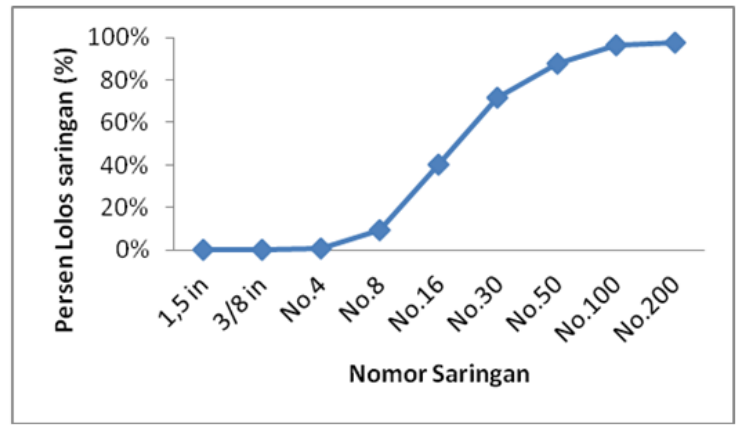

c) Sampel 3

The size of oil palm trunk to sample 3 is $25 \times 25 \mathrm{~cm}$. Results are reaping the stem size there are a lot of fiber size $0.075 \mathrm{~mm}, 0.15 \mathrm{~mm}, 0.60 \mathrm{~mm}$ and $1.18 \mathrm{~mm}$ while the size of the fiber that is at least $9.50 \mathrm{~mm}$. If seen from the graph 3 for the filter sample 3 can be said that the fiber distribution is not homogeneous samples 3 and fiber size has been very varied with the size of coarse fibers with a large amount is $1: 18 \mathrm{~mm}, 2.36 \mathrm{~mm}$ and $4.75 \mathrm{~mm}$.

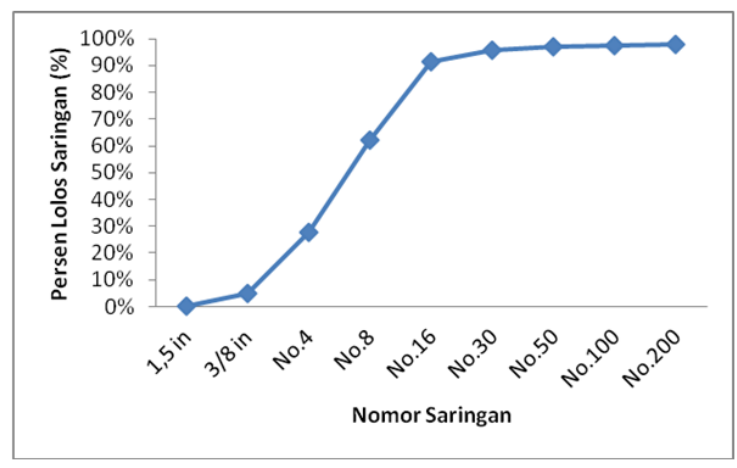

IV. Results and Discussion

Results of previous studies say that the palm trunk fiber has better quality because it has fiber length, fiber diameter which is the highest of the other non-timber fiber (Sigalingging S.R., 2011) then it potentially as a 
material particle board, fiberboard or papn composite. Factors taken into account in selecting a designer and builder of fiber board or fiber board as a partition wall is smooth surface, easy assembly, lightweight density, bending strength, fire proof, sound insulation and water proof (Kinanti, 2011).

From the results of sieve analysis in all three samples, the distribution type fibers that occur can be categorized on the continuous distribution. This type of fiber distribution makes it possible to reduce the number of pores and increase the values of density particle boards from oil palm trunk fiber.

In addition, it can also affect the level of sound absorption or the acoustic value of the board. The higher the density fiber particle boards, the value increased sound absorption coefficient (Sabri, Akram, 2014).

\section{Conclussion}

Based on the results of sieve analysis is performed on oil palm trunk in producing fibers show varying sizes so that the fiber distribution is said to be very good. So that the mixture of fiber sizes can be used as materials for particle board, fiber board or composite board.

\section{Acknoledgement}

Thank you to Ministry of Research, Technology and Higher Education for funding the research by Competitive Grant (Hibah Bersaing) 2016, University Negeri Medan and University of Sumatera Utara.

\section{Refferences}

[1] Bakar E. S., Rachman O., Hermawan D., Karlinasari L., and Rosdiana N. 1998. Utilization of oil palm trunk as building and furniture materials (1): Physical and chemical properties and durability of oil palm trunk. Journal of Forest Products Technology 11(1), 1-12.

[2] Iswanto A.H., Azhar I., Coto Z., Febrianto F. 2010. Sifat Fisis dan Mekanis Batang Kelapa Sawit (Elaeis guineensis Jacq) Asal Kebun Aek Pancur-Sumatera Utara. Jurnal Ilmu dan Teknologi Hasil Hutan 3(1):1-7.

[3] Sabri, Akram. 2014. Pemanfaatan papan partikel limbah kayu meranti dengan perekat damar sebagai panel alternatif penyerap bunyi. Prosiding Seminar Nasional Hasil Riset dan Standarisasi Industri IV: 109-116.

[4] Sigalingging S. R. 2011. Produksi dan Mutu Serat dari Batang Kelapa Sawit [Skripsi]. Departemen Kehutanan Fakultas Pertanian. Medan : USU.

[5] Kinanti, W. 2011. Composite Cement Interior Wall Partition Board. Jurnal Ilmu Pengetahuan dan Teknologi Terapan 6(2):181184. 